\title{
PENGATURAN SUHU UNTUK MENGATASI BAYI TERBAKAR BERBASIS ARDUINO DAN LABVIEW PADA INFANT INCUBATOR
}

\author{
Dicky Rivaldo Ramdani'), Andi Kurniawan Nugroho ${ }^{2)}$, Budiani Destyningtias ${ }^{3)}$ \\ ${ }^{1,2,3)}$ Program Studi Teknik Elektro, Fakultas Teknik, Universitas Semarang \\ Jalan Soekarno Hatta - Tlogosari, Semarang \\ *e-mail: dickyrivaldo@ymail.com ${ }^{1)}$, andikn@email.com ${ }^{2}$, destyningtias@usm.ac.id ${ }^{3)}$
}

\begin{abstract}
An incubator is a place designed to maintain a certain temperature condition. Incubators are often found in hospitals and farms. In hospitals, the Incubator functions to warm newborns, or premature babies. On farms, this incubator is usually used for egg hatchers and as a place for newly hatched chicks. Incubators are usually in the form of a room or box (box) of a certain size. In this research will be designed a prototype to modify the infant incubator by adding sensors to regulate the temperature and control using a Arduino microcontroller. This incubator has a measurement system and temperature regulation using LM35 sensors, heaters and fans as actuators that can cool the incubator room with Arduino as controlling. Temperature setting will be monitored by LABVIEW. In the Arduino system a program can be set up that can adjust the temperature. The temperature required by the premature baby, so that it can maintain the stability of the temperature. If the temperature in the incubator is smaller than the temperature setting, the heater will turn on and the fan speed will decrease to increase the temperature according to the settings entered. If the temperature in the incubator is greater than the temperature setting entered, the heater will turn off. The results showed that the linear regression value between the temperature values with the $A D C$ value of $y=0.4883 x$ with a determination coefficient of 1 , while the linear regression value between the temperature with a voltage value of $y=99.481 x$ with a coefficient of 0.9984 .
\end{abstract}

Keywords: Infant Incubator, temperature sensor, LM35.

\begin{abstract}
ABSTRAK
Infant Incubator merupakan suatu tempat yang dirancang untuk mempertahankan keadaan temperatur tertentu. Incubator banyak dijumpai pada rumah sakit dan peternakan. Pada rumah sakit, Incubator berfungsi untuk menghangatkan bayi yang baru lahir, atau bayi yang lahir prematur. Pada peternakan, inkubator ini biasanya digunakan untuk penetas telur dan sebagai tempat dari anak ayam yang baru menetas. Incubator biasanya berbentuk ruangan atau box (kotak) dengan ukuran tertentu. Pada penelitian ini akan dibuat alat untuk memodifikasi infant incubator dengan menambahkan sensor untuk mengatur suhu dan mengontrol menggunakan mikrokontroller Arduino supaya menghindari bayi terbakar. Incubator ini memiliki sistem pengukuran dan pengaturan suhu menggunakan sensor LM35, aktuator berupa Heater dan kipas yang dapat menyejukkan ruangan inkubator dengan arduino sebagai pengendali. Hasil pengaturan suhu ditampilkan melalui LABVIEW. Pada system Arduino akan ditanamkan sebuah program yang dapat diatur nilai suhunya sesuai dengan suhu yang diperlukan oleh bayi premature, sehingga dapat menjaga kestabilan suhu tersebut. Jika suhu didalam incubator lebih kecil dari setting suhu maka heater akan menyala dan kecepatan kipas angin akan menurun untuk menaikkan suhu sesuai dengan setting yang dimasukkan. Jika suhu didalam incubator lebih besar dari setting suhu yang dimasukkan maka heater akan mati. Hasil penelitian menunjukkan nilai regresi linier antara nilai suhu dengan nilai ADC sebesar $\mathrm{y}=0.4883 \mathrm{x}$ dengan nilai koefisien determinasi sebesar 1 , sedangkan nilai regresi linier antara suhu dengan nilai tegangan sebesar y $=99.481 \mathrm{x}$ dengan nilai koefisien sebesar 0.9984 .
\end{abstract}

Kata Kunci: Infant Incubator, sensor suhu, LM35.

\section{Pendahuluan}

I ncubator merupakan suatu tempat yang dirancang untuk mempertahankan keadaan temperatur tertentu. Inkubator banyak dijumpai pada rumah sakit dan peternakan. Pada rumah sakit, Inkubator berfungsi untuk menghangatkan bayi yang baru lahir, atau bayi yang lahir prematur. Pada peternakan, inkubator ini biasanya digunakan untuk penetas telur dan sebagai tempat dari anak ayam yang baru menetas. Inkubator biasanya berbentuk ruangan atau box (kotak) dengan ukuran tertentu. Incubator merupakan lingkungan atau daerah yang terisolasi dengan tidak debu, bakteri dan memiliki kemampuan untuk mengendalikan suhu, kelembaban dan oksigen[1]. Infant incubator perlu dilengkapi dengan pengaturan suhu sesuai dengan kebutuhan suhu yang diperlukan oleh baby premature. Baby premature memerlukan suhu ruang sebesar $36^{\circ} \mathrm{C}$ $-38^{\circ} \mathrm{C}$, sehingga diperlukan modifikasi incubator bayi untuk mempertahankan suhu tersebut. Kelemahan dari penelitian ini adalah tidak dilengkapi dengan system control atau system kendali secara otomatis untuk mengontrol suhu sehingga suhu tidak bisa secara otomatis menyesuaikan suhu ruang atau setting suhu[2]. Penelitian yang dilakukan oleh Hafidz dan Nyoman, 2012 membuat sebuah prototype baby incubator transport untuk memonitor suhu skin, pengaturan suhu dari $32^{\circ} \mathrm{C}-37^{\circ} \mathrm{C}$ dan kelembaban $70 \%-80 \% \mathrm{RH}$, pada 
alat ini dilengkapi dengan charge agar dapat dipindahkan. Penelitian ini dilengkapi dengan display seven segmen untuk menampilkan nilai suhu[3]. Pada penelitian yang dilakukan oleh ali, 2015 tentang modifikasi infant warmer yang dilengkapi dengan phototherapy menjelaskan tentang infant warmer untuk bayi baru lahir untuk mengatur suhu ruang yang diperlukan oleh bayi, tetapi pada penelitian ini tidak dapat dilakukan pengaturan secara otomatis[3].

Pada penelitian ini akan dikembangkan sebuah prototype yang digunakan untuk memodifikasi infant incubator dengan pengaturan suhu dan pengontrolan menggunakan mikrokontroller Arduino. Suhu pada incubator bisa di kontrol secara otomatis sesuai dengan nilai setting suhu yang diinginkan atau yang dibutuhkan oleh bayi premature. Infant incubator dilengkapi dengan sensor LM35 untuk mengetahui suhu pada Inkubator sendiri. Pengaturan suhu dilakukan menggunakan keypad $4 \times 4$ dan hasil pengaturan suhu ditampilkan pada LCD 16x2 dengan Arduino mikrokontroler yang kemudian informasi tentang kondisi suhu dalam Inkubator ditampilkan pada seven segment melalui aplikasi pengontrol otomatis berbasis mikrokontroler arduino yang dihubungkan dengan tampilan personal computer berbahasa Labview

\section{METODE PENELITIAN}

Metode yang digunakan pada penelitian ini menggunakan dua perancangan yaitu perancangan hardware dan perancangan software.

\section{A. Perancangan Hardware}

Perancangan hardware dari sistem infan incubator ditunjukkan pada Gambar 1.

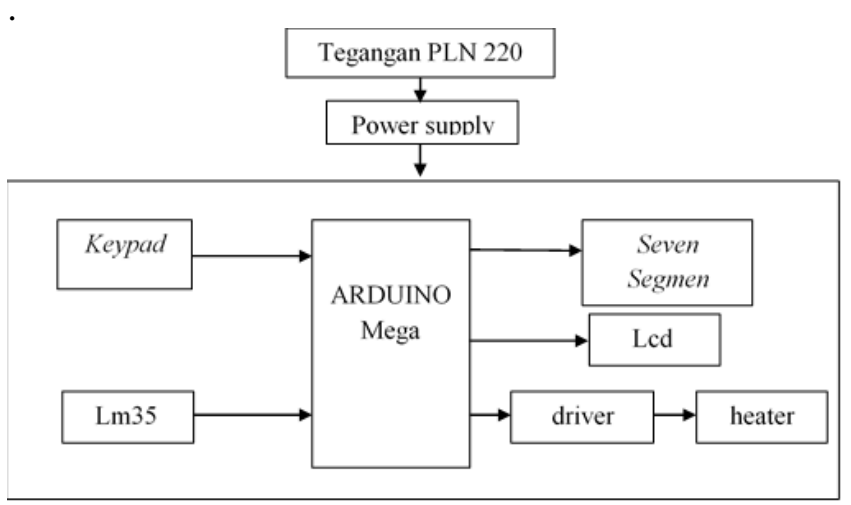

Gambar 1 Blok Diagram Infant Incubator

Gambar 1 menunjukan sistem secara keseluruhan dalam infant inkubator dengan pengaturan suhu dan labVIEW. Komponen-komponen dalam system infant incubator dengan pengaturan suhu berbasis Arduino dan labview antara lain: (1) Arduino mega yang digunakan untuk pusat perintah atau main prosessor karena seluruh perintah dikendalikan oleh mikrokontroller Arduino mega, (2) Keypad berfungsi untuk mengatur setting suhu yang akan di masukkan dalam infant incubator, (3) LCD (Liquid Crystal Display) sebagai display pembacaan nilai suhu yang dimasukkan melalui keypad, (4) Sensor suhu LM35 untuk mendeteksi suhu incubator, apabila nilai setting suhu yang dimasukkan kurang dari nilai suhu yang dikehendaki maka heater akan menyala tetapi jika setting suhu yang dimasukkan lebih dari suhu yang di inginkan maka heater akan mati, (5) Seven Segmen sebagai penampil suhu yang menempel pada infant incubator dan (6) Heater sebagai pemanas infant incubator.

\section{B. Perancangan Software}

Perancangan software merupakan salah satu bagian penting dalam penelitian ini karena setiap program disimpan dalam mikrokontroler Arduino. Program kompiler yang digunakan adalah Arduino 1.6.5. Arduino 1.6.5 merupakan software open-source Arduino Integrated Development Enviroment (IDE) yang digunakan di Windows, Mac, OS, dan Linux. Software Arduino environment ditulis dalam bahasa Java berdasarkan pada Processing. Bahasa pemrograman Arduino didasarkan pada bahasa pemrograman C[4][5][6] . Program yang dibuat akan diisikan ke dalam sebuah EEPROM yang ada di dalam mikrokontroler, sehingga program tersebut sudah dapat dijalankan oleh mikrokontroler.

Software pemrograman yang digunakan untuk memonitor atau menampilkan hasil pengaturan adalah LabVIEW[7]. labVIEW menggunakan bahasa pemrograman berbasis grafis atau blok diagram. Pada labVIEW, user pertama-tama membuat user interface atau front panel dengan menggunakan control dan indikator, yang dimaksud dengan kontrol adalah knobs, push buttons, dials dan peralatan input lainnya sedangkan yang dimaksud dengan indikator adalah graphs, LEDs dan peralatan display lainnya. Setelah menyusun user interface, lalu user menyusun blok diagram yang berisi kode-kode VIs (Virtual Instrumen) untuk mengontrol front panel. Setiap VI menggunakan fungsi-fungsi yang menggerakkan masukan dari pemakai antarmuka atau sumber lain dan menampilkan informasi itu atau memindahkannya ke file lain atau ke komputer lain. VI berisi tiga komponen yaitu (1)Panel muka digunakan untuk melayani antarmuka pemakai, (2) Diagram Block berisi source code grafis yang menggambarkan fungsifungsi VI, (3) Icon dan Connector Panel digunakan untuk Mengidentifikasi VI sedemikian rupa sehingga anda dapat menggunakan VI di dalam VI yang lain atau disebut dengan sub VI atau juga disebut dengan sub routine didalam program berbasis text. ketiga komponen dalam panel LabVIEW ditunjukkan pada Gambar 2. 


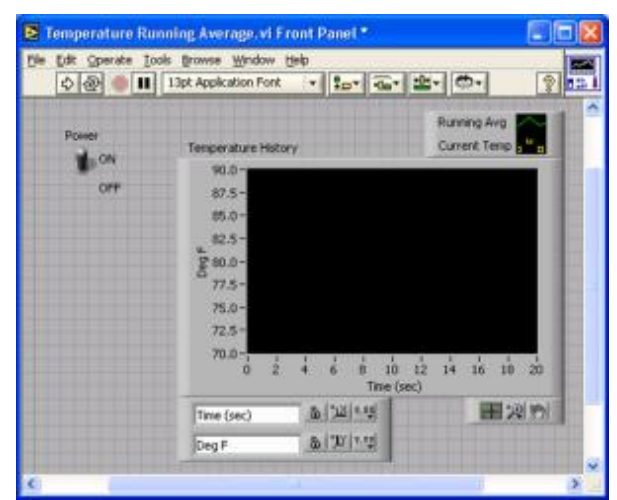

Gambar 2. Front Panel LabVIEW

\section{HASIL DAN PEMBAHASAN}

Hasil dan pembahasan pada penelitian ini meliputi pengujian sensor suhu LM35 dan pengujian sistem pengendalian pada labVIEW.

\section{A. Pengujian Sensor Suhu LM35}

Sensor Lm35 diuji dengan cara memberikan tegangan 5 volt pada vec sensor, kemudian tegangan keluaran atau output diukur melalui pengukuran pin keluaran menggunakan multimeter. Hasil pengujian sensor suhu LMdengan dilakukan dengan cara pengecekan pada pin keluaran dengan menggunakan multimeter. Hasil pengujian sensor suhu LM35 ditunjukkan pada Tabel 1 dan pengujian sistem kontrol arduino ditunjukkan pada Gambar 3.

Tabel 1. Hasil Pengujian sensor suhu LM35

\begin{tabular}{cc}
\hline Suhu & Tegangan keluar \\
\hline $24.90^{\circ} \mathrm{C}$ & $0.25 \mathrm{~V}$ \\
$30.27^{\circ} \mathrm{C}$ & $0.30 \mathrm{~V}$ \\
$34.677^{\circ} \mathrm{C}$ & $0.35 \mathrm{~V}$ \\
$36.62^{\circ} \mathrm{C}$ & $0.37 \mathrm{~V}$ \\
$39.55^{\circ} \mathrm{C}$ & $0.40 \mathrm{~V}$ \\
$42.97^{\circ} \mathrm{C}$ & $0.43 \mathrm{~V}$ \\
\hline
\end{tabular}

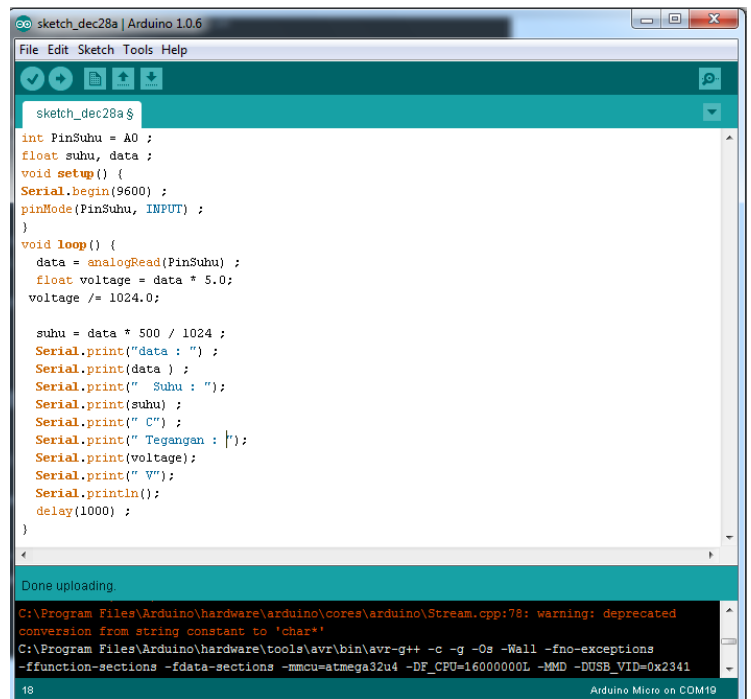

Gambar 3. Tampilan sistem kontrol arduino
Program IDE arduino memungkinkan kita untuk menuliskan baris program yang dapat membaca data sensor LM35 yaitu dengan mengubah data analog sensor menjadi data digital pada arduino. Data sheet dari LM 35 digunakan untuk mendapatkan nilai suhu yang akurat. Perubahan suhu adalah $10 \mathrm{mv} /$ derajat celsius. Persamaan yang digunakan untuk menkonversi nilai analog tersebut dengan menghitung nilai ADC yang masuk kemudian mengkonversikannya menjadi nilai tegangan milivolt. Arduino yang digunakan adalah ADC 10bit yaitu 1024 dan tegangan referensi sebesar 5Volt. Berdasarkan hal tersebut didapatkan persamaan yang digunakan untuk pengaturan suhu dalam arduino, yaitu

derajat celsius $=(\operatorname{adc} / 1024) * 5000 / 10$

suhuC = analogRead(suhuPin); //membaca nilai adc sensor

suhuC $=($ suhuC $/ 1024.0) * 5000 ; / /$ konversi data analog menjadi milivolt

suhuC $=$ suhuC $/ 10 ; / /$ konversi kedalam derajat celsius dengan persamaan 1 derajat $/ 10 \mathrm{mv}$

Sehingga kita dapat membuat rumus persamaan tersebut pada program seperti pada persamaan 1 dan persamaan 2 .

$$
\begin{aligned}
\text { Tegangan } & =\text { Nilai Sensor } x \frac{5}{1024} \\
\text { Suhu } & =\frac{500 \times \text { Data ADC }}{1024}
\end{aligned}
$$

Sensor Tegangan $=$ Nilai Sensor $\mathrm{x} \frac{5}{1024}=51 \times \frac{5}{1024}$ $=0,249$ Volt

Temperatur $=\frac{500 \times \text { Data Adc }}{1024}=\frac{500 \times 51}{1024}=24,92{ }^{\circ} \mathrm{C}$

Gambar 4 menunjukkan hubungan antara nilai suhu dengan nilai tegangan yang hasilkan oleh sistem infant inkubator.

\section{SUHU TERHADAP TEGANGAN}

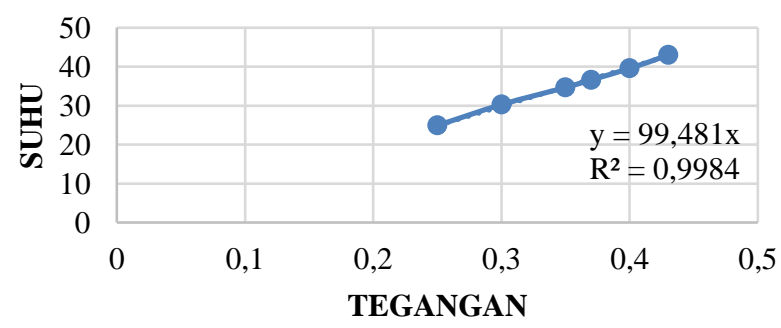

Gambar 4. Grafik antara Suhu Terhadap Tegangan sensor suhu LM 35

Pada gambar4 dapat diketahui nilai regresi linier pada grafik y $=99,481 x$. Dimana $x$ adalah Tegangan dan y adalah suhu yang dihasilkan. Nilai koefisien determinasi pada regresi linier $\left(\mathrm{R}^{2}\right)$ adalah 0,9984. sedangkan nilai ADC dengan nilai suhu ditunjukkan pada gambar 5 . 


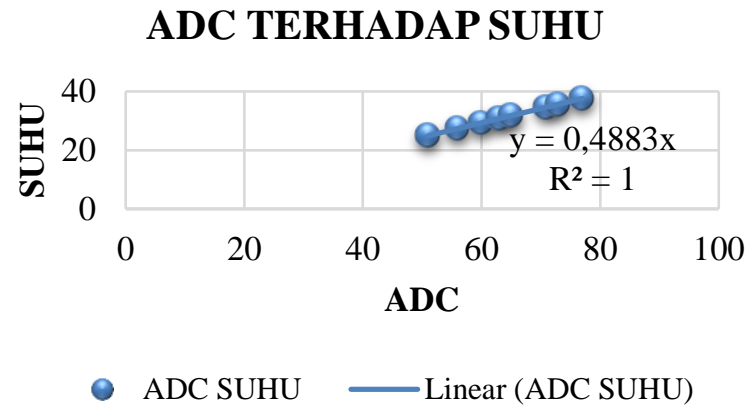

Gambar 5. Grafik antara suhu dengan nilai ADC

Pada gambar 5 dapat diketahui nilai regresi linier pada grafik y $=0,4883 x$. Dimana $\mathrm{x}$ adalah data $A D C$ dan y adalah suhu yang dihasilkan. Nilai koefisien determinasi pada regresi linier $\left(\mathrm{R}^{2}\right)$ adalah 1 .

\section{B. Pengujian LabVIEW}

Pengujian Labview ini digunakan memonitoring hasil dari output temperatur yang dihasilkan dari sistem infant incubator. Software Labview ini terdapat dua program yaitu program blok diagram dan Front panel. Gambar 6 dan Gambar 7 adalah blok diagram dan front panel yang telah di uji kan dengan arduino.

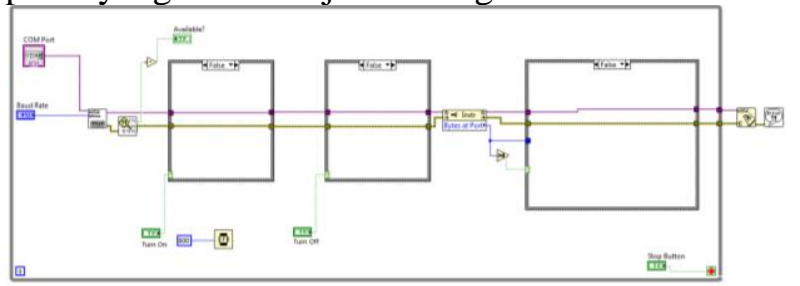

Gambar 6 Program dengan Blok Diagram

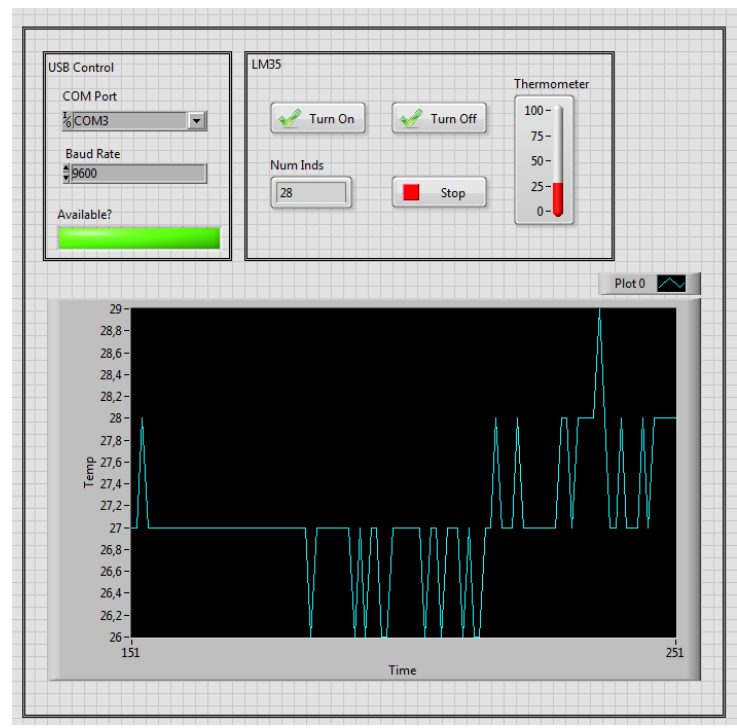

Gambar 7 Program Front Panel

\section{Analisa Data}

Settingan suhu yang disimpan pada mikrokontroler arduino mega yaitu $30^{\circ} \mathrm{C}$ lalu heater menyala sampai suhu yang dicapai. Suhu pada saat ruang invansi adalah $25^{\circ} \mathrm{C}$, untuk mencapai suhu $30^{\circ} \mathrm{C}$ membutuhkan waktu selama 3 menit dan kestabilan suhu di monitoring dengan software Labview agar mengetahui secara realtime waktu yang dibutuhkan untuk mencapai suhu yang disimpan. Tampilan suhu pada seven segment ditunjukkan pada gambar 8 .

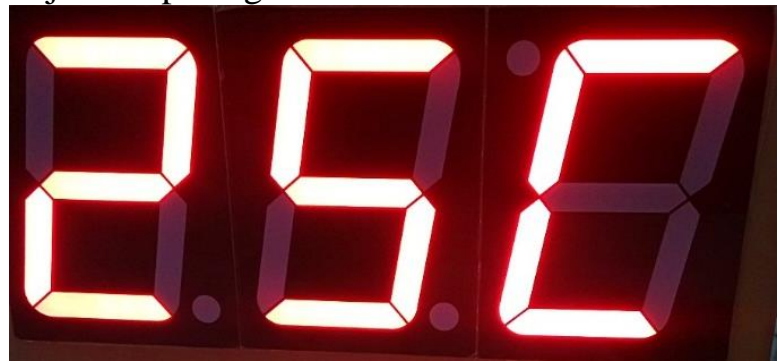

Gambar 8. Tampilan suhu dengan seven segmen

\section{KESIMPULAN}

Sistem modifikasi infant incubator dapat bekerja dengan baik untuk mengatur suhu yang dibutuhkan oleh bayi agar terhindar dari kebakaran atau bayi terbakar. hasil monitoring nilai pengaturan suhu dan tegangan di tunjukkan melalui program labVIEW, sehingga nilai suhu tersebut dapat di monitor secara real time. jika setting suhu pada infant incubator kurang dari suhu ruang yang di butuhkan bayi maka heater akan menyala, sebaliknya jika setting suhnya lebih besar dari suhu yang perlukan maka heater akan mati.

\section{SARAN}

Pengaturan suhu infant incubator dikembangkan dengan pengaturan kelembaban ruang karena untuk menghindari bayi terbakar selain suhu, diperlukan juga kelembaban yang sesuai yaitu antara $70 \%$ sampai dengan $80 \%$.

\section{DAFTAR PUStaka}

[1] Maulana,Hafidz,2012, Prototype Baby Incubator Transport, [Online]. Tersedia: http://digilib.poltekkesdepkes-sby.ac.id/public/POLTEKKESSBYStudi-674-drafseminar.pdf

[2] Wardani, Wisnu Kusuma, 2015, Modifikasi inkubator bayi dilengkapi kontrol suhu dan rangkaian charge[Online]. Tersedia: http://digilib.poltekkesdepkes-sby.ac.id/public/POLTEKKESSBYStudi-675-drafseminar.pdf

[3] Nurwanto, ALi, 2015, Modifikasi infant warmer dilengkapi phototherapy [Online]. Tersedia: 
http://digilib.poltekkesdepkes-sby.ac.id/public/POLTEKKESSBY-Studi-2633-

DRAFTSEMINAR.pdf

[4] Santoso, Hari. 2016. "Panduan Praktis Arduino Untuk Pemula"
[5] Kadir, Abdul., 2013, Panduan Praktis Mempelajari Aplikasi Mikrokontroler dan Pemrogramannya menggunakan Arduino, Yogayakarta: Andi Komputindo

[6] https://herwins.wordpress.com/labview/ 